CAse 3.-Matilda H., xiat. 3, of a strumous habit, was attacked with great restlessness, pain in the head, and a quick but feeble pulse. The skin was of an ordinary temperature; the howels were not confined. The eyes of this patient had that peculiar squint considered by medical men as a sure indication of the existence of water in the brain. T'he same medical gentlemen being called in, and fearing lest this case should prove fatal, called in Mr. Simmons, when they agreed in consultation to adopt a different plan of treatment. The pacient was allowed a generous diet, and tonic and stimulant medicines were administered. To the surprise of both practitioners, neither of whom had anticipated a favourable result, the little patient on their next visit was considerably improved, and gradually recovered.

Were not the symptoms of the two unsuccessful cases aggravated by bleeding, and are we not warranted, reasoning from analogy, in supposing that the accumulation of the serum found in the ventricles of the brain after death, was the consequence of the great abstraction of blood, and not the cause of the supposed inflammatory symptoms? Dr. Marshall Hall bas published some valuable remarks on the effects of loss of blood, which are well worthy the atten. tion of every practitioner. Dr. Hall's observations on this subject coincide with those made by Dr. Gooch ; for he says, "I have frequently known the effects of loss of blood, to be mistaken for inflammation of the brain." Do not let it be supposed that I wish to deprecate the use of leeches in affections of the heads of children; on the contrary, I think that when inflammation is known to be going on in any part of the head, abstraction of blood by leeches is the only effectual way of putting a stop to its progress. But there are cases, the symptoms of which greatly resemble those produced by inflammation, but which are caused by a deficiency of blood, by a want of nervous power in the system, and which are only to be successfully combated by supporting the patient.

"I bave many times," says Mr. Abercrombie, in his excellent work on Diseases of the Brain, "seen children lie a day or two in a kind of stupor, and recover under the use of wine and nourishment. It is often scarcely to be distinguished from the coma which accompanies diseases of the brain."

In the cases above related, the pulse was quick, but feeble; the skin was cold, and the constitution previous to the attack of illness, was greatly debilitated by want of proper nourishment. These circumstances must guide the practitioner in his treatment. When he finds his patient labouring under symptoms of cerebral disease, combined with a feeble pu'se, cold shin, and a con- stitution naturally delicate, he may be sure that the symptoms indicative of an inflammatory affection of the brain, arise from a deficiency of nervous energy, and require for their removal every-thing calculated to support and strengthen the constitution. From an inattention to these circumstances, many fatal errors have been committed.

16, Rock Street, Portman Square.

Sept. 1830.

\section{PROFESSIONAL REMINISCENCES.}

No. II.

MIDWIFERY CASES. ULCERATED I.EGS.-

TRUE BENEYOLENCE.-DROPSY,-HERNIA. - CANCER.

I TAKE the advantage of a leisure hour to resume my pen, which is so much the easier task from my having pledged myself to no consecutive tissue of narrative or course of argument. I shall, therefore, without referring to my former paper, consult my memory, and proceed according to its dictates in the same desultory style.

That paper closes with cases of midwifery. To these I shall only at present add one or two more. I was the medical attendant during the birth of a first child. and first placenta out of three in a case of triplets. Each child had its separate placenta. In every case of twins that I have seen, both navel strings were inserted into one placenta of a somewhat larger than the average size. The spontaneous detachment of the first placenta after the birth of the first child, and this without being followed by the slightest hrmorrhage on its removal, was not the least singular circumstance attending this case. I was at that time an assistant. The gentleman with whom I lived was one of the most skilful accoucheurs in that part of the country. It was during his temporary absence that I supplied his place. As the case, both previously to delivery and afterwards, was but partially and incidentally under my care, I only have it in my power to mention that the patient did well, and that the children lived some weeks. Both children and after-births were very small.

I have one other little case to mention, which occurred more entirely under my own eye. A patient of mine, after a labour of some duration, accompanied with considerable hæmorrhage, gave birth to an apparently still-born child. The snuff box of a neighbour being at hand, it struck me that (without consulting Denman or Merriman) it would be no unwise thing to take a small pinch out of it, and administer to the 
child. As it will not do at such junctures to be very reclserche in one's choice of remedies, I placed a little on the child's lip, and blew it up its nostrils. I found this summary process answer the end as well, or perhaps better, than any more elaborate stimulant. 'The child very speedily sneezed, and showed other unequivocal symptoms of vitality, and though for some time very weakly, and destined to go through many struggles for its life, it is living at this time, a nice bealthy child of near three years old.

I bave given these two cases without note or comment; but I will make now a fow remarks upon them. When any opinion we form in science appears to ourselves a doubtful one, it is best to set it down as such, and so leave it to abide the test of experience and observation.

In the last case of twins I attended, (both of the clildren being now, as their first appearance promised that they would be, alive and healthy,) the after-birth was larger than the three separate after-births in the triplet case put together. Is it, or is it not, the case ceteris paribus, and on the average, that fine healthy children have large afterbirths? Again, it is popularly believed that the occurrence of hemorrhage in any great degree, particularly duriug the latter period of gestation, "spoils" the child's "longevity." It does not seem unreasonable to conclude that the vis vite of a child must be weakened and enfeebled from this cause, though by no means irrecoverably. When hæmorrhage during labour is rery great, and has lasted long unchecked, we naturally expect to see a still-born child, and it is seldom that we have the pleasure of being agreeably disappointed. I do not promise to relinquish finally the subject of midwifery, but I shall for the present shift the scene, and commence a fresh train of reminiscences; some of them, perhaps, less strictly professional than the foregoing, but all of them owing their origin to my opportunities as a medical man, and the places which I have filled, and situations in which $I$ bave found myself in that capacity.

The first professional nuisance I learned to deprecate occurred to $\mathrm{me}$, in 1817.18 , when pupil to the late Jacob Jones, Esq., of Finsbury Square, who was surgeon to a public dispensary, I had to dress certain ulcers in the legs, (of annual, or sometimes perennial nature,) the property of poor people, who, ill fed and ill clad, were in the babit of drinking as much gin as they could get by way of counter-irritant to the general ailment of poverty and destitution. The consequence of this was a cacbectic habit of body very unfavounable to the consummation of any curative process. Healthy pus would be secreted-healthy granulations would form, and every-thing would go on swimmingly for a tire, when on a sudden, some morning on removing the bandage and dressing, behold, a black livid-looking patch-the walls of the ulcer giving way and enlarging, and all our work to do over again! In vain we tried ung. picis, ung. hyd. nitrat., sprinkling with pulv. rhei., and a succession of stimulants and refrigerants, and what not, aided by the most careful bandaging; our labours were frequently like those of Sisyphus. Even when at length they wcre dismissed cured, experience taught us to be sparing of our orations, for there was no telling how soon, like Monsieur Tonson, they would come again. 'I dare say several fresh generations of ulcerated legs have in due course flourished since my time, to the edification of my successors in office. I may speak on this subject con amore, and the more feelingly, as the duty of dresser devolved mostly on myself. Such sores are much more manageable in the country. Diseases in London and in the country differ, and require different treatment. This holds good among the poor especially. There is much sense and knowledge of human nature (I mention this en passant) in a piece of advice to dram-drinkers which I met with some time since in a popular pamphlet. Persons who wish to break off a habit which, to say the least of it, is injurious to the constitution, are recommended to substitute a pinch of snuff for a glass of gin every time they want one, as being the more harmless stimulant of the two. There is no doubt that in this way the task of reformation would prove easier. The facilities afforded us by nature for breaking off evil habits and mal-associations, bodily and mental, are ample and numerous. The ability to make use of these constitutes a species of versatility of mind, which it is very desirable to cultivate. But I perceive that my paper is taking a transcendental turn.

To descend from these cloudy regions of semi-metaphysics, I remember it was about this time that Mr. Jones assisted with food, money, and, what, considering his immense practice at that time, was a greater boon than either, his professional advice and attendance, a man who had lapsed from a state of affluence into poverty, and who himself, in the adranced stage of decline, was living in an upstairs room, which contained one bed for the joint accommodation of himself, a wife, and four childrell. It was my part to visit them occusionully, both for and with Mr. Jones. He had been an officer in a dragoon regiment, and had given $900 l$. for his commission. This he, through imprudence or misfortune, was at length obliged to sell, and having no knowledge of any means of earning 
money, had gradually sunk lower and lower rated, Mr. Camplin (Mr. Jones's partner, in the scale of adversity. But let me not and now his successor) succeeded on a last depict his condition in too dark colours. As attempt, in reducing it effectually. I need instructive a moral lesson might be read to not say that the taxis, tobacco enemas, and us, on the vanity of human apprehensions every possible remedy, had been resorted to, as on the vanity of human wishes. His before the operation was contemplated. sufferings were probably more apparent But it is worth remembering that at the than real ; in a great measure insensible to very last point of time left for such an exthe presence of surroundiug calamities, he periment, five minutes' continual pressure was for the most part employed in thinking should bave been successful in reducing it, of another world, at first with anxiety, and and saving a patient from a painful and hazard. afterwards with bope. Thus circumstanced ous operation. At the same time, I am with regard to worldly matters, let the afraid that I cannot say I rejoiced at this world guess who visited this deserted and unfortunate gentleman in sickness and af. fliction? His brother officers - his gay companions of but a few years previous? No! By them he was probably forgotten. They either knew not of his adverse circumstances, or took no care for them. Who then befriended him in affliction? A few faithful men among the Wesleyan Methodists; - the un paid, voluntary emissaries of the Benevolent Society visited him, relieved his temporal necessities, partly from the funds of the society, partly from their own private purses. Their kindness to. wards him was manifested with delieacy, and without ostentation; and through their charitable attentions and religious counsels, he enjoyed those comforts which sickness needs, and died "fearing God," and in a state of calm and peaceful preparation for a better, world which monarchs might envy. In fact, I know no society on the face of the earth by which a greater aggregate of unmixed good is effected. The only claim the objects of this charity have occasion to make, is founded on the humble merit of their being human creatures in distress, and such as bear this character, without seeking aid, are ind ustriously soughtout and relieved as far as the funds of the society will admit, often aided, as in this instance, by private and extempore benefactions.

Among the many dispensary patients whom I saw at their abodes in Golden Lane, Grub Street, London Wall, and other streets or their courts and alleys, was a woman who had ovarian dropsy, on whom I saw Mr. Jones perform the operation of tapping, about once every seven weeks, for the space of two years. It was not till some years after the first operation that she at length died. 'The recovery of a gentleman from dropsy of the abdomen, after having been tapped three times by Mr. Jones, also occurs to my memory. I have somewhere by me the minutes of his case, but cannot now find them. I remember about the same time, a case of narrow escape from the operation for incarcerated femoral hernia, in which, after the scalpels had been placed in order on the table by the late Mr. Taunton of Hatton Garden, who was to bave opeprorogation sine die of the said operation so much as I should. I believe I was guilty of entertaining some slight sensations of in. voluntary disappointment.

I would fain repeat some aneedotes which struck me much in Taunton's lectures, but I begin to think I have written enough for one time. The motto of a reminiscent ought to be

\section{Glissez mortels-n'appuyez pas.}

Accordingly, to avoid fatiguing my reader or myself, I shall now close No. II., with a recollection of more recent date.

The first case of chimney-sweeper's cancer that has occurred to me in my private practice, has proved a very satisfactory one in its results. About this time last year, a man in the neighbourhood of Wyeombe who followed this occupation, showed me a small hard tumour in the axilla which had for some time been painful. The pain extended across the pectoral muscle in the course of the absorbent vessels, and was so great, that he was very willing to submit to any operation. As there appeared no doubt, of the nature of the tumour-as there was a chance of its progressing and extending, and under any circumstances of its becoming large, and increasingly perilous to remove, and as (moreover) his father had died of a similar complaint,-I advised him to let me remove it. This I accomplished with little diffculty, and complete success. The wound went on favourably, and he has had no pain in the part, nor has any tumour formed there or elsewhere since. The tumour (which I have kept by me preserved in spirits), when cut open, exhibited very distinctly that incipient cancerous structure which is called scirrhus. As the wound was small, to make assurance doubly sure, I touched the bottom of the wound with lunar caustic, in order to destroy any fibres belonging to the removed tumour that might remain.

Once more I subscribe myself, Sir, Yours obediently, S. Gow ER.

High Wycombe, Bucks. Sept. 17 th, 1830. 